\title{
Diabetes Mellitus in Hepatitis C Patients Presenting to Tertiary Care Facility, Nawabshah
}

\author{
Arslan Badar, Shehzad Memon, Kashif Ali, Muhammad Zarrar, Yar Muhammad, Naveed Sattar Shaikh
}

\begin{abstract}
Background: Increased incidence has been found for diabetes and hepatitis $C$. The most common mechanism involved is the insulin resistance that interferes in hepatocytes with insulin signaling and cause inflammatory mediators release with increasing oxidative stress. Objective: To determine the frequency of diabetes mellitus in Hepatitis $C$ patients presenting to tertiary care facility, Nawabshah. Study Design: Cross Sectional Study. Settings: Medicine Department of People's University of Medical \& Health Sciences for Women Nawabshah District Shaheed Benazirabad, SindhPakistan. Duration: From 4th August 2016 to 3rd February 2017. Methodology: Total 137 patients with HCV RNA seropositive, diagnosed by PCR with or without liver cirrhosis of duration more than 2 years and either of gender were included. Patients were diagnosed for diabetes mellitus if Glycated hemoglobin $(\mathrm{HbA} 1 \mathrm{C}) \geq 6.5 \%$. Data was collected via self-made proforma. Results: There were 72 male and 65 female subjects. Mean age was $43.75 \pm 10.55$ years. Mean $\mathrm{HBA} 1 \mathrm{C}$ was $6.53 \pm 0.60 \%$. Mean duration of $\mathrm{HCV}$ was $4.71 \pm 0.96$ years. $59.1 \%$ patients have liver cirrhosis. Diabetes mellitus was observed in $45(32.8 \%)$ cases. Significant correlation of liver cirrhosis, gender, and age was observed with diabetes among HCV patients. While no significant correlation was found with duration of HCV. Conclusion: Type 2 diabetes mellitus was observed high (32.8\%) among hepatitis $\mathrm{C}$ positive patients.
\end{abstract}

Keywords: Diabetes Mellitus, Hepatitis C, Liver Cirrhosis.

Corresponding Author Submitted for Publication: 11-10-2019 Accepted for Publication: 12-12-2019

DR. KASHIF ALI, Assistant Professor of Medicine \& Allied, Peoples University of Medical and Health Sciences for Women, Nawabshah-Pakistan. Contact / Email: +92 333-2700149, fazlanikashif@gmail.com

Citation: Badar A, Memon S, Ali K, Zarrar M, Muhammad Y, Shaikh NS. Diabetes Mellitus in Hepatitis C Patients, Presenting to Tertiary Care Facility, Nawabshah. APMC 2020;14(1):58-61.

\section{INTRODUCTION}

Infection with the Hepatitis $\mathrm{C}$ virus (HCV) is a significant global health problem. Prior World Health Organization (WHO) released global infection burden statistics cover just the burden of acute HCV infections. ${ }^{1,2}$ Estimates suggest that 3 to 4 million individuals are freshly contaminated annually, 170 million individuals are infected chronically and at a risk of getting hepatic disease involving cirrhosis and hepatic cancer, and 0.35 million deaths occur annually because of all causes linked to HCV. ${ }^{3}$ Chronic HCV represents around $3 \%$ of populace with 150 200 million people are affected every year worldwide with 0.17 billion HCV patients are at risk of acquiring liver cirrhosis or malignancy. 2,4

Numerous studies have indicated that HCV infection can also lead to the progression to diabetes mellitus (DM), and a greater incidence of type 2 diabetes mellitus (T2DM) in the developing world $(2 \%$ to $9.4 \%)$ in HCV patients than in subjects with other types of chronic hepatitis has been observed. ${ }^{5}$ In 1994, Allison et al were the first to find correlation between DM and HCV infection. ${ }^{6} \mathrm{HCV}$ infections have been reported as among the major causes of severe sequelae of chronic hepatic disease including liver cancer and end-stage cirrhosis. ${ }^{7}$ In addition, there have been many extra hepatic complications correlated with chronic $\mathrm{HCV}$ disease. ${ }^{8}$ Allison initially made the assumption that $\mathrm{HCV}$ could be correlated with T2DM. ${ }^{7}$ From then on, several observational studies have been reported which evaluated the relationship between T2DM and HCV. Several studies confirming the excessive risk of T2DM with $\mathrm{HCV}$ infection. ${ }^{9}$ In 2008, An observational studies-based meta- analysis revealed an excess T2DM risk with HCV infections. ${ }^{10}$ $\mathrm{HCV}$ is by far the most frequent cause for hepatocellular carcinoma and cirrhosis in the U.S. ${ }^{11,12}$ Additionally, a variety of significant extra hepatic manifestations are associated with $\mathrm{HCV} .{ }^{13}$ Of these, a body evidence indicate that Infection with $\mathrm{HCV}$ raises the risk of T2DM and a resistance to insulin. However, previous evidence suggested that HCV infection raises the risk of DM by around 4 folds in populations over the age of $39 .{ }^{14}$

Increased incidence has been observed for DM and HCV ranging from $10 \%-58.3 \%$ An uncertain mechanism is thought to be involved but some of the studies advocate HCV's direct interference with insulin receptor by releasing the proinflammatory cytokines. Elhawary et al reported $13.84 \%$ patients of HCV seropositive to have mostly T2DM. ${ }^{15}$ To avoid potentially fetal infection, prompt diagnosis and treatment of subjects at risk for serious hepatic disease from chronic $\mathrm{HCV}$ is necessary. Recent data has shown intrinsic mechanism involving diabetes with advancement of hepatic disease among HCV patients. ${ }^{16,17}$

Nevertheless, the most common mechanism involved is the insulin resistance that interferes in hepatocytes with insulin signaling and cause inflammatory mediators release with increasing oxidative stress. The Pakistan Medical Research Council has also documented raised prevalence of HCV among patients with DM than the normal population. ${ }^{11}$ The current study is aimed at determining the DM frequency in HCV patients, presenting to tertiary care facility Nawabshah. 


\section{METHODOLOGY}

Study Design: Cross Sectional Study.

Settings: This study was carried out at Department of Medicine,

Peoples University of Medical \& Health Sciences for Women, Nawabshah, District Shaheed Benazirabad, Sindh Pakistan.

Duration: Six months from 3rd August 2016 to 2nd February 2017.

Sample Technique: Non-probability consecutive sampling.

Sample Size: Sample size was calculated by taking prevalence of $13.84 \%$, confidence level $95 \%$ and margin of error $6 \%$, so the sample size was 137 .

Inclusion Criteria: Age 20 to 60 years, either gender. HCV RNA seropositive patients diagnosed by PCR with or without presence of liver cirrhosis. Duration of HCV more than 2 years. Exclusion Criteria: Patients with hepatocellular carcinoma, Patients with end stage kidney disease, Patients with coexisting viral infection such as hepatitis B surface antigen positive patients and Pregnant women.

Methods: Data were collected from seropositive HCV RNA patients who visited outpatient department or were admitted in Medicine department of Peoples University of Medical \& Health Sciences (for women), Nawabshah. Well-versed consent was received from the study participants by researcher.

Furthermore, brief history of age, gender, HCV, source of inclusion (OPD/Ward) was noted on proforma. This information along with demographic was noted. Ultrasound of the patient was done for presence of echotexture and portal vein diameter $>1.2 \mathrm{~cm}$. Patients were diagnosed of diabetes mellitus if Glycated hemoglobin $(\mathrm{Hb} \quad \mathrm{A} 1 \mathrm{C}) \geq 6.5 \%$. All the data was recorded via self-made proforma.

Data Analysis: The SPSS.20 was used for statistical analysis. Mean and standard were calculated for HCV duration age of the patients. The qualitative variables like gender, source of inclusion, liver cirrhosis and DM were presented in terms of percentages and frequencies. Stratification was done regarding gender, age, HCV duration and liver cirrhosis. Post stratification Chi-square test was applied and a P-value $<0.05$ was considered as significant.

\section{RESULTS}

The results showed that there were 72 male and 65 female patients and overall mean age was $43.75 \pm 10.55$ years. The overall mean HBA1C of study subjects was $6.53 \pm 0.60 \%$. The overall mean duration of $\mathrm{HCV}$ was $4.71 \pm 0.96$ years. Out of 137 study subjects most of patients $81(59.1 \%)$ have liver cirrhosis. Table 1

In our study, diabetes mellitus was found in $45(32.8 \%)$ patients. The frequency distribution is presented in fig- 1 .

Stratification with respect to age, gender and liver Cirrhosis was done to observe effect of these modifiers on diabetes mellitus. The results revealed significant correlation of with liver cirrhosis $(p=0.018)$, gender $(p=0.00)$ and age $(p=0.05)$ with diabetes among HCV patients. While no significant correlation was found with duration of $\mathrm{HCV}(\mathrm{p}=0.387)$ with diabetes mellitus among these patients. Table 2.

Table 1: Demographic information of the patients $=137$

\begin{tabular}{|l|c|c|}
\hline \multirow{2}{*}{ Variables } & \multicolumn{2}{c|}{ Statistics } \\
\hline \multirow{2}{*}{ Gender } & Male & $72(53 \%)$ \\
\cline { 2 - 3 } & Female & $65(47 \%)$ \\
\hline \multirow{2}{*}{ Cirrhosis of liver } & Yes & $81(59.1 \%)$ \\
\cline { 2 - 3 } & No & $56(40.9 \%)$ \\
\hline Age (mean+SD) & \multicolumn{2}{|c|}{$43.75 \pm 10.55$ years } \\
\hline HbA1c (mean+SD) & \multicolumn{2}{|c|}{$6.53 \pm 0.60$} \\
\hline HCV duration (mean+SD) & \multicolumn{2}{|c|}{$4.71 \pm 0.96$ years } \\
\hline
\end{tabular}

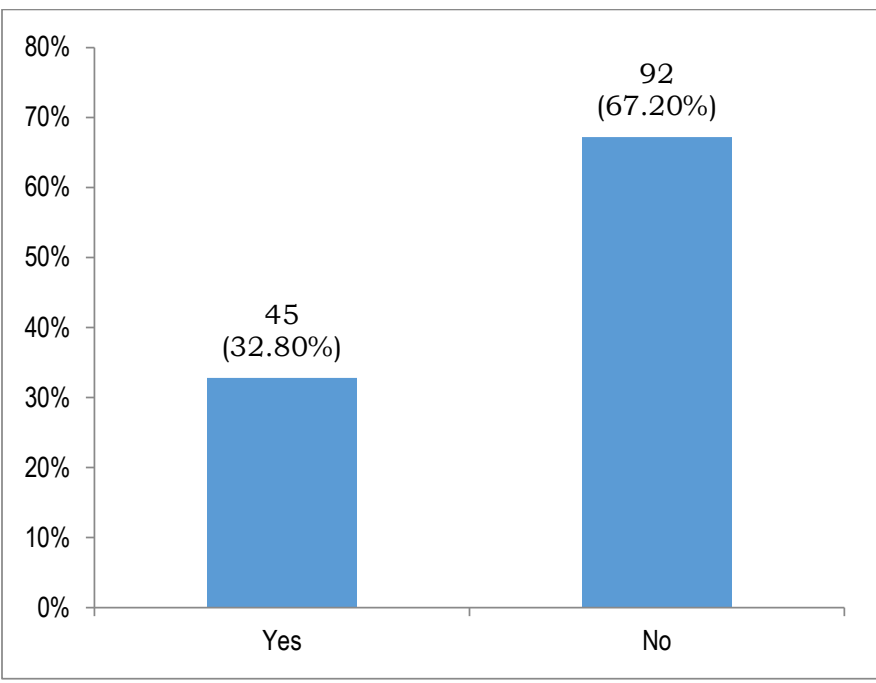

Figure 1: Frequency of diabetes mellitus among HCV infected patients $n=137$

Table 2: Frequency of diabetes mellitus according to the age, gender, cirrhosis and duration of HCV $=137$

\begin{tabular}{|c|c|c|c|c|c|}
\hline \multicolumn{2}{|c|}{ Variables } & \multicolumn{2}{|c|}{ Diabetes mellitus } & \multirow[b]{2}{*}{ Total } & \multirow[b]{2}{*}{$\begin{array}{c}p- \\
\text { value }\end{array}$} \\
\hline \multirow{3}{*}{ Age groups } & & $\begin{array}{c}\text { Yes } \\
(n=45)\end{array}$ & $\begin{array}{c}\text { No } \\
(n=92)\end{array}$ & & \\
\hline & $\begin{array}{c}<45 \\
\text { years }\end{array}$ & 29 & 43 & 72 & \multirow{2}{*}{0.054} \\
\hline & $\begin{array}{c}>45 \\
\text { years }\end{array}$ & 16 & 49 & 65 & \\
\hline \multirow{2}{*}{ Gender } & Male & 41 & 31 & 72 & \multirow{2}{*}{0.001} \\
\hline & Female & 4 & 61 & 65 & \\
\hline \multirow{2}{*}{$\begin{array}{c}\text { HCV } \\
\text { duration }\end{array}$} & $\begin{array}{l}\leq \leq 4 \\
\text { years }\end{array}$ & 18 & 44 & 62 & \multirow{2}{*}{0.387} \\
\hline & $>4$ years & 27 & 48 & 75 & \\
\hline \multirow{2}{*}{ Cirrhosis } & Yes & 33 & 48 & 81 & \multirow{2}{*}{0.018} \\
\hline & No & 12 & 44 & 56 & \\
\hline
\end{tabular}

\section{DISCUSSION}

Diabetes mellitus (DM) and Hepatitis $\mathrm{C}$ virus (HCV) cause overwhelming longstanding complications among a significant number of patients. It wouldn't be shocking to connect the two conditions. Infection with chronic HCV can trigger cirrhosis that 
generally leads the patient to DM via IR. Current cross-sectional research conducted worldwide indicate they are strongly related indeed. ${ }^{18}$ Most of the prior investigations have reported a correlation between T2DM and HCV infections. There is a study that detects raised risk of T2DM in HCV subjects because above $25 \%$ of Chronic HCV subjects had DM. ${ }^{19}$ Qureshi et al in their study from Karachi showed that DM was present among $24.5 \%$ of HCV positive cases. ${ }^{20}$ One more systematic Review meta-analysis reported that $19.67 \%$ of $\mathrm{HCV}$ infection cases had DM. ${ }^{21}$ Riaz S, et a ${ }^{22}$ observed that type II DM was $27 \%$ among chronic HCV infected patients. Allison et al reported that among cirrhosis patients who were looking forward for transplantation, $\mathrm{HCV}$ infected patients were 5 folds more expected to have T2DM as compared to those who did not have HCV, irrespective of sex, severity of hepatic disease or BMI. ${ }^{6}$

Rising age has been reported to be a major cause of T2DM among HCV infected subjects because $68.2 \%$ of DM patients were aged $>45$ years. ${ }^{19}$ It is stated that patients older than 39 years, HCV infection developed almost four times high risk of diabetes mellitus. ${ }^{24}$ Diabetic family history was observed as a major risk factor for T2DM development among chronic HCV patients, ${ }^{23}$ and this study evidences the same because above $50 \%$ of diabetics had positive family history for DM.

Samir et al in favor of current study reported that there was a significantly raised incidence of DM among HCV infected subjects than those who had HBV infection (56.5\% vs $2.7 \%$ respectively). ${ }^{25}$ Obesity has proved to be one of the most significant risk factors of T2DM. In present study, around quarter of diabetics had BMl below $25 \mathrm{~kg} / \mathrm{m} 2$. Narita et al reported a correlation of BMI with raised risk of DM among HCV genotypeI and -II patients and among individuals without any DM related family history. ${ }^{26}$ Due to obesity epidemic and diabetes rates increasing as the results, the metabolic effects linked with hepatitis $\mathrm{C}$ infection and its eradication are very essential to consider. ${ }^{27}$

\section{CONCLUSION}

In conclusion, among hepatitis C positive patients, type 2 diabetes mellitus had a high frequency (32.8\%).

\section{LIMITATIONS}

Study with a small sample size, conducted in a single Medical Department are the limitation of this study.

\section{SUGGESTIONS / RECOMMENDATIONS}

Thus, every hepatitis $C$ virus infected patient is recommended to be suspected for type II DM.

\section{CONFLICT OF INTEREST / DISCLOSURE}

No conflict of interest.

\section{ACKNOWLEDGEMENTS}

Authors have acknowledged to the seniors and friends for their technical support.

REFERENCES
1. Hanafiah MK, Groeger J, Flaxman AD, Wiersma, S. Global epidemiology of hepatitis $C$ virus infection: new estimates of agespecific antibody to HCV seroprevalence. Hepatology 2013:57(4):1333-42

2. Global Burden of Disease Hepatitis C Working Group. Global burden of disease (GBD) for hepatitis C. J Clin Pharmacol. 2014;44:20-9.

3. Perz JF, Armstrong GL, Farrington LA, Hutin YJ, Bell BP. The contributions of hepatitis $B$ virus and hepatitis $C$ virus infections to cirrhosis and primary liver cancer worldwide. J Hepatol. 2016;45(4):529-38

4. Lozano R, Naghavi M, Foreman K, Lim S, Shibuya K, Aboyans $\mathrm{V}$, et al. Global and regional mortality from 235 causes of death for 20 age groups in 1990 and 2010: a systematic analysis for the Global Burden of Disease Study 2010. Lancet. 2012;380(9):2095-2128.

5. Lonardo A, Adinolfi LE, Petta S, Craxì A, Loria P. Hepatitis C and diabetes: the inevitable coincidence?. Expert review of antiinfective therapy. 2019;7(3):293-308

6. Allison ME, Wreghitt T, Palmer CR, Alexander GJ. Evidence for a link between hepatitis $C$ virus infection and diabetes mellitus in a cirrhotic population. J Hepatol. 1994;21(6):1135-56

7. Naing C, Mak JW, Ahmed SI, Maung M. Relationship between hepatitis $C$ virus infection and type 2 diabetes mellitus: metaanalysis.World J Gastroenterol. 2012;18(14):1642-51.

8. Mauss S, Berg T, Rockstroh J, Sarrazin C, Wedemeyer $\mathrm{H}$, editors. Hepatology - A Clinical Textbook. 2nd ed. Dusseldorf: Flying publisher, 2010:19-27.

9. Hammerstad SS, Grock SF, Lee HJ, Hasham A, Sundaram N, Tomer $Y$. Diabetes and hepatitis C: a two-way association. Frontiers in endocrinology. 2015;6:134.

10. White DL, Ratziu V, El-Serag HB. Hepatitis $C$ infection and risk of diabetes: a systematic review and meta-analysis. J Hepatol 2018;49(5):831-44.

11. Younossi ZM, Stepanova M, Nader F, Younossi Z. Associations of chronic hepatitis $C$ with metabolic and cardiac outcomes. Aliment Pharmacol \& Therap 2013;37(6):647-52.

12. Davis GL, Alter M, El-Serag H, Poynard T, Jennings LW. Aging of hepatitis $\mathrm{C}$ virus (HCV)-infected persons in the United States: a multiple cohort model of HCV prevalence and disease progression. Gastroenterology. 2010;138(2):513-21.

13. Jacobson IM, Cacoub $P$, Dal ML, Harrison SA, Younossi ZM. Manifestations of chronic hepatitis $C$ virus infection beyond the liver. Clin Gastroenterol Hepatol 2010;8(12):1017-29.

14. Mehta SH, Brancati FL, Sulkowski MS, Strathdee SA, Szklo M, Thomas DL. Prevalence of type 2 diabetes mellitus among persons with hepatitis $C$ virus infection in the United States. Ann Intern Med 2000;133(8):592-9.

15. Elhawary E, Mahmoud GF, El-Daly MA, Mekky FA, Esmat GG, Abdel-Hamid M. Association of HCV with diabetes mellitus: an Egyptian case-control study. Virology J. 2011;8:367.

16. Ansari S, Ghani H, Afzal Junejo S. Frequency of Retinopathy in Hundred Cases of Chronic Hepatitis C on Interferon Therapy at Liaquat University Hospital Hyderabad. Med Chan. 2010;16(2):240-3.

17. Elkrief L, Chouinard P, Bendersky N, Hajage D, Larroque $B$ Babany $\mathrm{G}$, et al. Diabetes- mellitus is an independent prognostic factor for major liver related outcomes in patients with cirrhosis and chronic hepatitis C. Hepatology. 2014;60(3):823-31.

18. Alexander GJ. An association between hepatitis $C$ virus infection and type 2 diabetes mellitus: what is the connection? Ann Intern Med. 2000;133(2):650-2. 
19. Ghouri A, Kumar S, Ahmed Khan S, Hanif Ghani M, Aslam S. Frequency of Type 2 Diabetes Mellitus in Patients with Chronic Hepatitis C Virus Infection. JLUMHS. 2014;13(2):51-6.

20. Qureshi H, Ahsan T, Mujeeb SA, Jawad F, Mehdi I, Ahmed W, et al. Diabetes mellitus is equally frequent in chronic HCV and HBV infection. J Pak Med Assoc. 2012;52(7):280-3.

21. Ambachew S, Eshetie S, Geremew D, Endalamaw A, Melku M. Prevalence of Type 2 Diabetes Mellitus among Hepatitis $C$ VirusInfected Patients: A Systematic Review and Meta-Analysis. In J Diabet Meta. 2018;21(1-4):29-37.

22. Riaz S, Qadri MS, Sohail K. Frequency of type 2 diabetes mellitus in patients with chronic hepatitis c virus infection. J Uni Med \& Dental Coll. 2015 Sep 3;6(3):32-7.

23. Drazilova S, Gazda J, Janicko M, Jarcuska P. Chronic hepatitis $C$ association with diabetes mellitus and cardiovascular risk in the era of DAA therapy. Canadian Journal of Gastroenterology and Hepatology. 2018;2018.

24. Reid M, Price JC, Tien PC. Hepatitis $C$ virus infection in the older patient. Infectious Disease Clinics. 2017;31(4):827-38.

25. Rouabhia S, Malek R, Bounecer H, Dekaken A, Bendali Amor F, Sadelaoud M, et al. Prevalence of type 2 diabetes in Algerian patients with hepatitis C virus infection. World J Gastroenterol. 2010;16(27):3427-31.

26. Narita R, Abe S, Kihara Y, Akiyama T, Tabaru A, Otsuki M. Insulin resistance and insulin secretion in chronic hepatitis $C$ virus infection. J Hepatol. 2014;41(1):132-8.

27. Hum J, Jou JH. The link between hepatitis $C$ virus and diabetes mellitus: Improvement in insulin resistance after eradication of hepatitis C virus. Clinical liver disease. 2018;11(3):73-6.

\section{AUTHORSHIP AND CONTRIBUTION DECLARATION}

\begin{tabular}{|c|c|c|}
\hline AUTHORS & Contribution to The Paper & Signatures \\
\hline $\begin{array}{l}\text { Dr. Arslan Badar } \\
\text { Senior Registrar Medicine } \\
\text { Peoples University of Medical and Health Sciences } \\
\text { for Women, Nawabshah Pakistan }\end{array}$ & Data collection and manuscript writing & 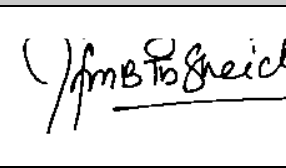 \\
\hline $\begin{array}{l}\text { Dr. Shehzad Memon } \\
\text { Senior Registrar Medicine } \\
\text { Peoples University of Medical and Health Sciences } \\
\text { for Women, Nawabshah Pakistan }\end{array}$ & Contribution in data collection and manuscript writing & \\
\hline $\begin{array}{l}\text { Dr. Kashif Ali } \\
\text { Assistant Professor of Medicine } \\
\text { Peoples University of Medical and Health Sciences } \\
\text { for Women, Nawabshah Pakistan } \\
\end{array}$ & Contribution in data analysis and manuscript writing & llay \\
\hline $\begin{array}{l}\text { Dr. Muhammad Zarrar } \\
\text { Assistant Professor of Medicine } \\
\text { Peoples University of Medical and Health Sciences } \\
\text { for Women, Nawabshah Pakistan }\end{array}$ & Review the manuscript and guideline in data analysis & $M / h d$ \\
\hline $\begin{array}{l}\text { Dr. Yar Muhammad } \\
\text { Assistant Professor of Medicine } \\
\text { Peoples University of Medical and Health Sciences } \\
\text { for Women, Nawabshah Pakistan }\end{array}$ & Review the literature & Yar_M \\
\hline $\begin{array}{l}\text { Dr. Naveed Sattar Shaikh } \\
\text { Assistant Professor of Nephrology } \\
\text { Peoples University of Medical and Health Sciences } \\
\text { for Women, Nawabshah Pakistan }\end{array}$ & Manuscript writing guidelines & \\
\hline
\end{tabular}

